\title{
Alveolar Epithelial Cell Therapy with Human Cord Blood-Derived Hematopoietic Progenitor Cells
}

\author{
Monique E. De Paepe, ${ }^{* \dagger}$ Quanfu Mao, ${ }^{\star \dagger}$ \\ Sailaja Ghanta, ${ }^{\ddagger}$ Virginia Hovanesian, ${ }^{\dagger}$ \\ and James F. Padbury ${ }^{\ddagger \S}$ \\ From the Departments of Pathology* and Pediatrics, ${ }^{\ddagger}$ Women \\ and Infants Hospital, Providence; and the Departments of \\ Pathology and Laboratory Medicine ${ }^{\dagger}$ and Pediatrics, ${ }^{\circledR}$ Alpert \\ Medical School of Brown University, Providence, Rhode Island
}

The role of umbilical cord blood (CB)-derived stem cell therapy in neonatal lung injury remains undetermined. We investigated the capacity of human CB-derived $\mathrm{CD} 4^{+}$hematopoietic progenitor cells to regenerate injured alveolar epithelium in newborn mice. Doubletransgenic mice with doxycycline (Dox)-dependent lung-specific Fas ligand (FasL) overexpression, treated with Dox between embryonal day 15 and postnatal day 3 , served as a model of neonatal lung injury. Singletransgenic non-Dox-responsive littermates were controls. $\mathrm{CD}^{4} 4^{+}$cells $\left(1 \times 10^{5}\right.$ to $\left.5 \times 10^{5}\right)$ were administered at postnatal day 5 by intranasal inoculation. Engraftment, respiratory epithelial differentiation, proliferation, and cell fusion were studied at 8 weeks after inoculation. Engrafted cells were readily detected in all recipients and showed a higher incidence of surfactant immunoreactivity and proliferative activity in FasL-overexpressing animals compared with non-FasL-injured littermates. Cord blood-derived cells surrounding surfactant-immunoreactive type II-like cells frequently showed a transitional phenotype between type II and type I cells and/or type I cell-specific podoplanin immunoreactivity. Lack of nuclear colocalization of human and murine genomic material suggested the absence of fusion. In conclusion, human CB-derived $\mathrm{CD}_{34^{+}}$cells are capable of longterm pulmonary engraftment, replication, clonal expansion, and reconstitution of injured respiratory epithelium by fusion-independent mechanisms. Cord blood-derived surfactant-positive epithelial cells appear to act as progenitors of the distal respiratory unit, analogous to resident type II cells. Graft proliferation and alveolar epithelial differentiation are promoted by lung injury. (Am J Pathol 2011, 178:1329-1339; DOI: 10.1016/j.ajpath.2010.11.062)
Premature infants treated with supplemental oxygen and mechanical ventilation are at risk for bronchopulmonary dysplasia (BPD) or chronic lung disease of the preterm newborn, a complex condition characterized by an arrest of alveolar development. ${ }^{1}$ Although surfactant therapy, antenatal steroids, and changes in neonatal intensive care have modified its phenotype, BPD remains a significant complication of premature birth. The main pathological hallmark of BPD is an arrest of alveolar development, characterized by large and simplified distal airspaces. $^{2-4}$ In addition, several reports ${ }^{5-7}$ have shown that the lungs of ventilated preterm infants with early BPD show markedly increased levels of alveolar epithelial cell death. Recently, it was demonstrated that increased alveolar epithelial apoptosis induced by Fas ligand (FasL) overexpression in newborn mice is sufficient to disrupt alveolar remodeling, ${ }^{8}$ supporting the notion that the loss of alveolar epithelial cells plays a critical role in the arrested alveolar development seen in BPD. These findings suggest that cell-based therapy aimed at restoring or protecting the alveolar epithelium in injured newborn lungs may be beneficial.

Multiple publications ${ }^{9-20}$ during the past decade have suggested that bone marrow-derived stem and progenitor cells can structurally engraft as mature differentiated airway and alveolar epithelial cells. Epithelial engraftment is suggested by some investigators ${ }^{20}$ to be a rare event, regardless of the marrow-derived cell type used or the type of antecedent lung injury. In fact, it has recently been questioned whether engraftment and transdifferentiation can occur at all, based on failure to duplicate these results using state-of-the-art morphological techniques. ${ }^{21-24}$ Even if several studies ${ }^{10,18,25-27}$ have reported seemingly unequivocal engraftment of donor-derived airway and/or alveolar epithelium after adult stem cell administration, functional reconsti-

Supported in part by the NIH [P20-RR18728 Center of Biomedical Research Excellence in Perinatal Biology to M.E.D.P. and J.F.P. and P20RR018757 Center of Biomedical Research Excellence (New Approaches to Tissue Repair) to M.E.D.P.].

Accepted for publication November 17, 2010.

Address reprint requests to Monique E. De Paepe, M.D., Department of Pathology, Women and Infants Hospital, 101 Dudley St, Providence, RI 02905. E-mail: mdepaepe@wihri.org. 
tution by and clonal expansion of the engrafted cells have, to our knowledge, not yet been demonstrated.

Although heavy experimental emphasis has been placed on marrow-derived stem cell therapies, little is known about the potential role of non-marrow-derived stem cells, such as those derived from umbilical cord blood (CB). Human umbilical CB is a readily available source of autologous hematopoietic stem cells, endothelial cell precursors, mesenchymal progenitors, and multipotent/pluripotent lineage stem cells. ${ }^{28-32}$ Cord blood stem cells can be collected at no risk to the donor, have low immune reactivity, have low inherent pathogen transmission, and are not subject to the social and political controversy associated with embryonic stem cells. Cord blood stem cells are particularly attractive in the newborn context in which, ideally, the infant's own CB-derived stem cells could be used as an autologous transplant.

Cord blood stem cells can be induced to differentiate along neural, cardiac, epithelial, hepatic, pancreatic, and dermal pathways. ${ }^{33-44}$ The role of CB-derived stem cells in lung repair remains largely unexplored. Recent studies $^{9,45,46}$ have shown that CB-derived mesenchymal stem cells can decrease lung injury and/or promote tissue repair after lung injury, even without significant engraftment as lung epithelial cells. The mechanisms underlying these mesenchymal stem cell-associated beneficial effects are not fully determined but are believed to be related, at least in part, to anti-inflammatory paracrine factors. ${ }^{47}$ Although the use of $\mathrm{CB}$ - or bone marrow-derived mesenchymal stem cells may lead to invaluable therapeutic strategies for older patients with end-stage lung disease, caution may be warranted before considering their use in younger age groups. Mesenchymal stem cells continue to be poorly characterized and not uniformly defined, compromising interpretation and comparison of results obtained in different laboratories. More ominously, there is increasing clinical and experimental evidence suggesting that mesenchymal stem cells may undergo malignant transformation and produce sarcomatous neoplasms. ${ }^{48-50}$ This diminishes the enthusiasm for use of these stem cells as a therapeutic modality in young children.

In contrast to mesenchymal stem cells, hematopoietic progenitor cells are better and more uniformly characterized, are more easily isolated, and have an excellent and long-standing safety record after decades of use in clinical transplantation. The aim of the present study was to determine, using state-of-the-art morphological techniques, whether human CB-derived $\mathrm{CD}_{3} 4^{+}$hematopoietic progenitor cells have the capacity to do the following: (1) engraft in injured newborn lungs, (2) undergo functional differentiation to respiratory epithelial cells, and (3) regenerate injured lung epithelium. As done in a previous study, ${ }^{24}$ we chose the intranasal/intrapulmonary route of administration rather than the systemic route for delivery of stem cells. The direct intrapulmonary delivery of stem cells may represent a biologically more sound strategy for restoration of the respiratory epithelium. ${ }^{24}$ Furthermore, the intrapulmonary route is highly clinically relevant. Because many preterm infants are intubated, intrapulmonary delivery via the endotracheal tube is within the scope of the current practice of administration of exogenous surfactant and antioxidants.

As a model of neonatal lung injury, we used our newly generated conditional respiratory epithelium-specific FasL-overexpressing transgenic mouse. ${ }^{8,51}$ When FasL overexpression is targeted to the perinatal period, this apoptosis-induced transgenic mouse model provides a faithful replication of both the early apoptotic injury and the subsequent alveolar simplification typical of preterm infants with BPD. 8,51

\section{Materials and Methods}

\section{Isolation of $\mathrm{CD} 34^{+}$Cells from Human $\mathrm{CB}$}

Human umbilical CB was obtained from uncomplicated full-term cesarean deliveries $(n=47)$ at Women and Infants Hospital, Providence, RI, according to protocols approved by the Institutional Review Board. Cord blood was collected in citrate-phosphate-dextrose whole blood collection bags (Baxter Health Care Corp, Deerfield, IL) and processed within 2 hours after delivery. Mononuclear CB cells were isolated by Ficoll-Hypaque density gradient centrifugation (Fisher BioReagents, Pittsburgh, PA). The CB-CD34+ ${ }^{+}$cells were isolated from mononuclear cell suspensions by immunomagnetic cell sorting (MACS) using anti-human CD34 microbeads, according to the manufacturer's instructions (Miltenyi Biotec, Bergisch Gladbach, Germany). ${ }^{52,53}$ $\mathrm{CD}_{3} 4^{+}$cell purity was determined by immunocytochemistry and flow cytometric analysis of the MACS product using a phycoerythrin-conjugated anti-human CD34 antibody (130-081-002; Miltenyi Biotec). Cell viability was determined by Trypan blue exclusion. Cell purity and viability were studied in eight randomly selected cell preparations.

\section{Animal Husbandry and Tissue Processing}

The previously described lung-specific FasL-overexpressing transgenic mouse ${ }^{8,51}$ was used as a model for neonatal lung injury/BPD. This model is based on a tetracycline-dependent tetracycline-inducible overexpression system to achieve time-specific FasL-transgene expression in the respiratory epithelium. ${ }^{8}$ Transgenic (tetOp) ${ }_{7}-\mathrm{FasL}$ mice ("responder line") were crossed with Clara cell secretory protein (CCSP)-rtTA mice ("activator line") (provided by Dr J. Whitsett, University of Cincinnati, Cincinnati, $\mathrm{OH})^{54}$ to yield mixed offspring of double-transgenic (CCSP-rtTA ${ }^{+} /\left[\right.$tetOp $_{7}-\mathrm{FasL}^{+}$) and single-transgenic (CCSP-rtTA ${ }^{+} /\left[\right.$tetOp $_{7}-\mathrm{FasL}^{-}$) littermates. On exposure to the tetracycline analog, doxycycline (Dox) double-transgenic mice $\left(\mathrm{CCSP}^{+} / \mathrm{FasL}^{+}\right)$exhibit marked pulmonary apoptosis, resulting in BPD-like alveolar disruption; single-transgenic littermates $\left(\mathrm{CCSP}^{+} / \mathrm{FasL}^{-}\right)$remain unaffected and serve as noninjured controls. ${ }^{8}$ The transgenic animals are generated in an FVB/N genetic background and have an intact immune system.

In this study, Dox $(0.01 \mathrm{mg} / \mathrm{ml})$ was added to the drinking water of pregnant and/or nursing dams from embryonal day 14 to postnatal day 3 (postnatal day 1 is the day 
of birth). The progeny (both $\mathrm{CCSP}^{+} / \mathrm{FasL}^{+}$and $\mathrm{CCSP}^{+} /$ FasL') were sacrificed at postinoculation day 2 or week 8 by pentobarbital overdose. Between 5 and 10 animals of each genotype and treatment group were studied at each point. Lungs were processed as previously described. ${ }^{8}$ All animal experiments were conducted in accordance with institutional guidelines for the care and use of laboratory animals.

\section{Intranasal Administration of $\mathrm{CB}-\mathrm{CD} 34^{+}$Cells to Newborn Mice}

At postnatal day 5 , CB-CD34 $4^{+}$cells $\left(1 \times 10^{5}\right.$ to $5 \times 10^{5}$ cells/pup) were delivered to Dox-treated double- or single-transgenic pups by intranasal administration, as previously described. ${ }^{24}$ Freshly isolated CB-CD34 ${ }^{+}$cells, derived from eight different $\mathrm{CB}$ cell preparations, were administered to newborn mice immediately after MACS sorting (ie, within 4 to 5 hours after CB harvesting). Sham controls received equal-volume PBS vehicle buffer. Intranasal inoculation was performed at postnatal day 5 because this point is characterized by marked alveolar epithelial cell apoptotic injury and remodeling in Dox-treated doubletransgenic $\mathrm{CCSP}^{+} / \mathrm{FaSL}^{+}$mice.

\section{Analysis of Engraftment of $\mathrm{CB}-\mathrm{CD} 34^{+}$Cells in Newborn Mouse Lungs}

Delivery of the intranasally administered CB-CD34 ${ }^{+}$ cells to distal airways and airspaces was studied at postinoculation day 2 by anti-human vimentin (N1521; DAKO, Glostrup, Denmark) immunohistochemistry. Antibody binding was detected by the streptavidin-biotin immunoperoxidase method. Long-term engraftment of CB-derived cells was assessed at 8 weeks after inoculation. The presence of human-derived cells was assessed by quantitative real-time RT-PCR analysis of human Alu sequences, according to methods described by McBride et al ${ }^{55}$ (Table 1). Genomic DNA was extracted from whole lung lysates using a kit (Wizard Genomic DNA Purification Kit; Promega Corporation, Madison, WI). Standard curves were generated by serially diluting human genomic DNA prepared from CB cells into murine genomic DNA using 50 ng of DNA per reaction.

In addition, the distribution of engrafted cells was studied by fluorescent in situ hybridization (FISH) analysis of FFPE lung tissues using two types of human chromosome-specific probes. The presence of cells of human

Table 1. Sequence of PCR Primers and Probe Used for Human Alu Quantitative RT-PCR

\begin{tabular}{cl}
\hline Variable & Sequence \\
\hline PCR primer & \\
Forward & 5'-CATGGTGAAACCCCGTCTCTA-3' \\
Reverse & 5'-GCCTCAGCCTCCCGAGTAG-3' \\
TaqMan probe & 5'-FAM-ATTAGCCGGGCGTGGTGGCG-TAMRA-3' \\
\hline
\end{tabular}

The primer and probe sequences used were as described by McBride et al. ${ }^{55}$ origin was verified by multicolor FISH analysis using chromosomes $\mathrm{X}$ and $\mathrm{Y}$ and 18-centromere enumeration probes (Vysis; Abbott Laboratories, Abbott Park, IL), according to the manufacturer's instructions. The selection of these probes was based on their routine successful application in our perinatal pathology/cytogenetics service. The tissue sections were placed on a coverslip with mounting media containing DAPI (Vector Laboratories, Burlingame, VT) and viewed using an epifluorescence microscope equipped with a DAPI/fluorescein isothiocyanate/Texas Red triplepass filter set.

We also performed FISH analysis with human-specific Alu probes, as described by Schormann et al. ${ }^{56}$ Briefly, tissue sections were deparaffinized and subjected to epitope retrieval in citrate buffer, $\mathrm{pH}$ 6.0. Sections were incubated with a fluorescein-labeled Alu probe (PR-100101; BioGenex, San Ramon, CA) and denatured at $95^{\circ} \mathrm{C}$ for 10 minutes, followed by overnight hybridization at $30^{\circ} \mathrm{C}$. After stringent washes and blocking of nonspecific binding sites by a streptavidin-biotin block (Vector Laboratories), detection of the human Alu probe was achieved using a biotinylated anti-fluorescein antibody (Vector Laboratories) followed by streptavidin-green fluorophore conjugate (Streptavidin-DyLite 488, Jackson ImmunoResearch, Baltimore, MD). Controls for specificity consisted of omission of probe or anti-fluorescein antibody, which abolished all staining. The slides were viewed by confocal microscopy, as previously described. ${ }^{24}$

\section{Analysis of Cell Fate of CB-CD34+ Cells in Newborn Mouse Lungs}

\section{Analysis of Epithelial and Respiratory Epithelial Differentiation}

The epithelial differentiation of $\mathrm{CB}-\mathrm{CD} 34^{+}$cells was assessed by streptavidin-biotin immunoperoxidase staining using a human-specific antibody against cytokeratin (M3515, AE1/3; DAKO). In view of the lack of humanspecific markers of respiratory epithelial cells that could be used to trace human donor cells in a murine background, further cell fate mapping was achieved by combinations of immunofluorescent double labeling. In the double-labeling studies, anti-human cytokeratin antibody was used as a marker of human (ie, CB-derived) epithelial cells, whereas the cell-specific antibodies were used to provide information about potential respiratory epithelial differentiation of the CB-derived engrafted cells.

Differentiation of human CB-derived $\mathrm{CD} 34^{+}$cells to alveolar type II cells was assessed by combining antihuman cytokeratin staining with anti-prosurfactant protein-C (SP-C) (ab28744, Abcam Inc., Cambridge, MA). To study the differentiation of donor-derived cells to alveolar type I cells, anti-human cytokeratin staining was combined with anti-T1 $\alpha$ (podoplanin) labeling ${ }^{57,58}$ (clone 8.1.1, Developmental Studies Hybridoma Bank, lowa City, IA). Differentiation of human cord blood-derived $\mathrm{CD} 34^{+}$cells to bronchial epithelial CCSP was assessed by combining anti-human cytokeratin staining with Clara 
Cell Secretory Protein [CCSP, Clara cell-10 (CC-10)] labeling (07-623, Upstate Technologies, Lake Placid, NY). All sections were viewed by confocal microscopy.

\section{Analysis of Proliferation}

The proliferative activity of engrafted CB-derived cells was assessed by combining human Alu-FISH analysis with anti-Ki-67 immunohistochemistry. Thus, human AluFISH analysis was performed as previously described, followed by incubation of the tissue sections with rabbit monoclonal anti-Ki-67 antibody (4203-1, Epitomics, Burlingame, CA), biotinylated anti-rabbit secondary antibody (Vector Laboratories) and, finally, streptavidin-red fluorophore conjugate (AlexaFluor 594-Streptavidin, Vector Laboratories). Similarly, the specific proliferative activity of CB-derived epithelial cells was assessed by doubleimmunofluorescence labeling using anti-human cytokeratin antibody in combination with anti-Ki-67 labeling, using previously described methods. ${ }^{4}$

\section{Analysis of Fusion}

Previous studies, based on heart and liver transplant models, have suggested that the presence of donorderived differentiated cells may be attributable, at least in part, to fusion of donor-derived stem or progenitor cells with mature recipient cells. Most well-described models of xenogeneic human to mouse transplantation in which fusion occurs, such as fusion of CB-CD34 ${ }^{+}$cells (or their progeny) with murine hepatocytes, are characterized by nuclear fusion, as demonstrated by the colocalization of donor (human) and recipient (murine) genome in the same nucleus. ${ }^{59-61}$ To investigate the occurrence of cellular fusion, FISH analysis with human chromosome-specific probes was combined with FISH analysis using mouse chromosome-specific probes (Pancentromeric Mouse Chromosome Paint, 1697-Mcy3-02; Cambio Ltd, Cambridge, UK). Sections were processed for Alu-FISH analysis, as previously described, with a single modification: at hybridization, tissues were incubated simultaneously with human Alu probes and Cy3-labeled pancentromeric mouse probes.

\section{Data Analysis}

Values are expressed as mean \pm SD. The significance of differences between groups was determined with the unpaired Student's t-test or analysis of variance, with a post hoc Scheffé test where indicated. $P<0.05$ was considered significant. Computer software (Statview; Abacus, Berkeley, CA) was used for all statistical work.

\section{Results}

\section{Harvesting of $\mathrm{CD} 34^{+}$Cells from Umbilical CB}

Umbilical CB was collected from 47 uncomplicated fullterm cesarean deliveries. The CB collection volume was $92.4 \pm 32.0 \mathrm{ml}$ (range, 39 to $191 \mathrm{ml}$ ). After Ficoll-gradient centrifugation, CB-derived mononuclear cells were subjected to MACS by positive selection using a kit (CD34 MicroBead Kit; Miltenyi Biotec). On average, $1.7 \pm 1.2 \times$ $10^{6} \mathrm{CB}-\mathrm{CD} 34^{+}$cells were isolated per placenta (range, $0.2 \times 10^{6}$ to $4.5 \times 10^{6}$ ). The CD34 ${ }^{+}$cell yield per unit of $\mathrm{CB}$ volume varied greatly between cases and ranged between $0.24 \times 10^{6}$ and $3.66 \times 10^{6} \mathrm{CD} 34^{+}$cells per 100-ml CB (mean \pm SD, $1.52 \pm 0.95 \times 10^{6} \mathrm{CD}^{+} 4^{+}$cells per $100 \mathrm{ml})$. CD $34^{+}$cell purity was greater than $95 \%$, as determined by flow cytometric and immunohistochemical analyses of cytospin preparations using fluorescein isothiocyanate-labeled anti-CD34 antibodies (data not shown). Cell viability after Ficoll centrifugation and MACS sorting, determined by Trypan blue exclusion, was greater than $92 \%$.

\section{Analysis of Early Distribution of CB-CD34 ${ }^{+}$ Cells in Lungs of Newborn Mice after Intranasal Administration}

Delivery of intranasally administered CB-CD34 ${ }^{+}$cells to distal airways and airspaces was monitored by anti-human vimentin immunohistochemistry at postinoculation day 2. Intranasal administration of $\mathrm{CB}-\mathrm{CD} 34^{+}$cells in newborn mice resulted in even and effective cellular distribution in both lungs (Figure 1, A and B), confirming previous results with murine whole bone marrow cells. ${ }^{24}$ Focal intra-alveolar macrophage collections were associated with degenerating donor-derived cells (Figure 1A). Intra-alveolar inflammatory aggregates and associated cellular debris appeared to be more prevalent in doubletransgenic recipients. There was no histopathological evidence of interstitial inflammation. Omission of primary anti-vimentin antibody abolished all immunoreactivity. Anti-human vimentin staining of lungs of control newborn mice that did not receive CB-CD $34^{+}$cells was negative. In initial experiments, we performed a survey of human vimentin immunoreactivity in other organs. No human vimentinimmunoreactive cells were detected in liver, spleen, bone marrow, or kidneys, suggesting that the early distribution of intranasally delivered donor cells was confined to the lungs. As previously reported, ${ }^{24}$ intranasal delivery was associated with cell loss in the gastrointestinal tract, as demonstrated by the occasional presence of human vimentinpositive cells in the stomach (data not shown).

\section{Analysis of Long-Term Engraftment of CB-CD34 ${ }^{+}$ Cells in Lungs of Newborn Mice}

Quantitative real-time RT-PCR analysis of lung lysates at postinoculation week 8 revealed the presence of human Alu DNA sequences in all recipient lungs, albeit at low levels (Figure 2). The amount of human Alu DNA recovered from lung homogenates varied greatly between animals but was comparable overall between single- and double-transgenic recipients: both the Alu DNA index (the amount of Alu PCR amplification product in lungs of CB-CD34 ${ }^{+}$recipients versus lungs of PBS-treated animals) and the fraction of human genomic DNA relative to total lung DNA were similar in both groups (Figure 2). 


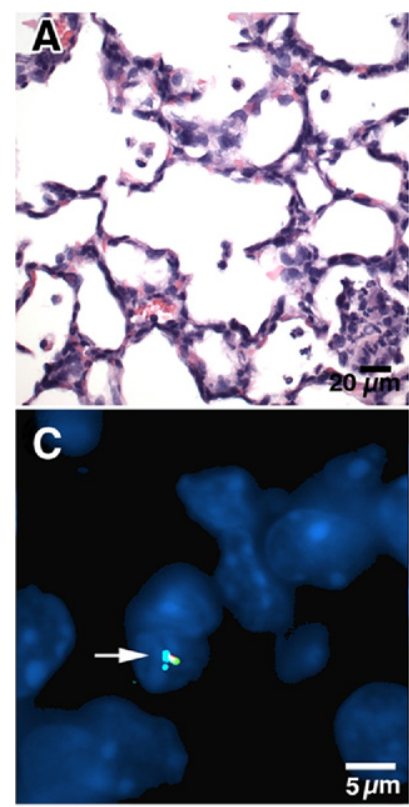

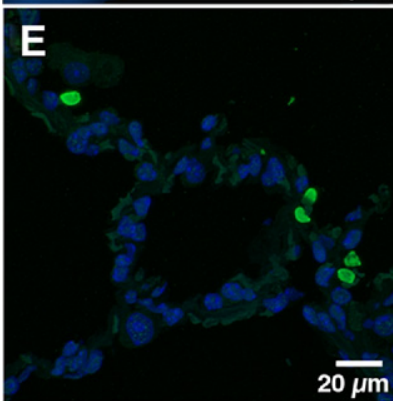

B
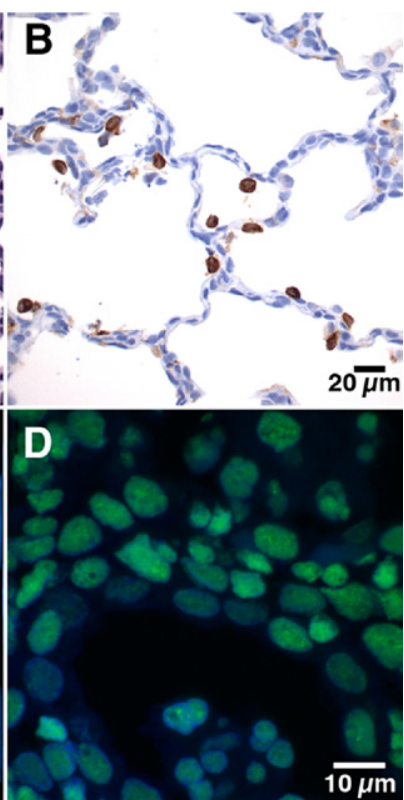

$\mathbf{F}$
Figure 1. Analysis of engraftment of intranasally delivered CB-CD $34^{+}$cells A: Postinoculation day 2 (postnatal day 7), double-transgenic recipient. Representative photomicrograph showing scattered mononuclear cells, consistent with $\mathrm{CB}-\mathrm{CD} 34^{+}$cells, in the airspaces. A mixed inflammatory aggregate associated with degenerating mononuclear cells is noted in the right lower corner (H\&E staining). B: Postinoculation day 2 (postnatal day 7), doubletransgenic recipient. Representative anti-human vimentin staining showing diffuse distribution of human CB-derived cells in the distal airways and airspaces. Murine mesenchymal cells, such as fibroblasts, endothelial cells, and peribronchial/perivascular smooth muscle cells, show no cross-reactivity with anti-human vimentin antibody, supporting its specificity for human cells (avidin-biotin peroxidase staining, hematoxylin counterstain). C: Postinoculation week 8, single-transgenic recipient. Human CB-derived cell (from male donor), labeled with color-coded probes complementary to human chromosomes $18, \mathrm{X}$, and $\mathrm{Y}$, is noted incorporated in the alveolar septum (arrow) (FISH analysis using human chromosome-specific centromeric probes, DAPI counterstain). D: Alu-FISH analysis of human postmortem lung tissue (positive control) showing nuclear positivity in all cells. E: Postinoculation week 8, double-transgenic recipient. Five CB-derived Alu FISH-positive cells are shown along the alveolar septum. Four cells occur as doublets (right), suggestive of recent replication. F: Postinoculation week 8, double-transgenic recipient. Three contiguous Alu-FISH-positive cells are noted along the alveolar septum, suggestive of clonal derivation from a common CB-derived precursor. An additional Alu-FISH-positive cell is present on the right [FISH analysis using human Alu-specific probes, DAPI counterstain (D-F)].

We used two types of FISH analysis to identify humanderived engrafted cells. The FISH analysis using human chromosomes $X$ and $Y$ and 18-centromere enumeration probes detected scattered human-derived cells in the alveolar septa (Figure 1C). However, interpretation of the results of conventional FISH analysis using color-coded centromeric probes was often hindered by the small size of the signal and high background noise. The FISH analysis using human Alu probes resulted in easily detectable and highly specific labeling of human-derived cells (Figure 1, D-F), thus allowing more reliable interpretation and quantitation of results. Alu-positive nuclei were readily identified in all animals that received a transplant (Figure $1, E$ and F). The engrafted cells were evenly distributed in central and peripheral lung parenchyma without obvious geographic predilection. Although most human cells were single, occasional aggregates of Alu-positive cells were identified within the same microscope field and in a paired or contiguous pattern, suggestive of clonogenic expansion (Figure 1, E and F).

To determine the effect of lung injury on the recovery rates of CB-derived cells at 8 weeks after inoculation, we compared the density of Alu-FISH-positive nuclei in Doxtreated double-transgenic animals with that in singletransgenic animals. The density of Alu-positive cells was similar in both groups $(5.6 \pm 1.3$ cells per 10 high-power fields in double-transgenic animals versus $4.7 \pm 1.4$ cells per 10 high-power fields in single-transgenic animals; four animals per group). Taken together, the quantitative RT-PCR and Alu FISH data suggest that intranasal inoculation of human CB-CD34+ cells in newborn mice results in long-term, stable pulmonary engraftment of CBderived cells, both in injured and non-injured lungs.

\section{Analysis of Cell Fate of CB-CD34 ${ }^{+}$Cells in Lungs of Newborn Mice}

\section{Analysis of Epithelial Differentiation}

Next, we assessed the potential of CB-CD34 ${ }^{+}$cells (or their progeny) to undergo epithelial differentiation by antihuman cytokeratin immunohistochemical analysis of lung tissues at 8 weeks after inoculation. Scattered, and occasionally clustered, human cytokeratin-positive cells were readily detected in all lungs (Figure 3). Some human cytokeratin-positive cells were large and ovoid or spherical, with ample cytoplasm. Others appeared more elongated and aligned with the alveolar wall (Figure 3). As demonstrated by the lack of staining in murine alveolar and bronchial epithelial cells, the anti-human cytokeratin monoclonal antibody proved to be specific for epithelial cells of human origin (Figure 3 ). Omission of primary antibody abolished all staining.

\section{Analysis of Respiratory Epithelial Differentiation}

The previous results indicate that intranasally delivered CB-CD $34^{+}$cells are capable of undergoing epithelial differentiation. To determine their capacity to undergo respiratory epithelial differentiation, we performed double-immunofluorescence labeling studies combining anti-human cytokeratin staining (as a marker of humanderived epithelial cells) with cell-specific respiratory or airway epithelial markers.

We first investigated whether CB-CD34+ ${ }^{+}$cells had the capacity to differentiate into alveolar type II cells, characterized by the presence of cytoplasmic immunoreactive surfactant-associated proteins. In the lungs of Dox-treated single-transgenic mice, only rare $(<1 \%)$ human-derived epithelial cells showed SP-C immunoreactivity (Figure 4 and 
A

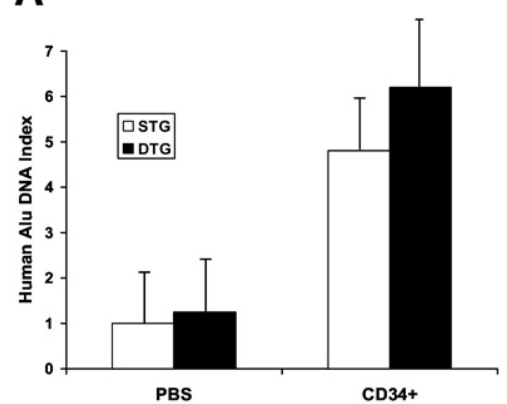

B

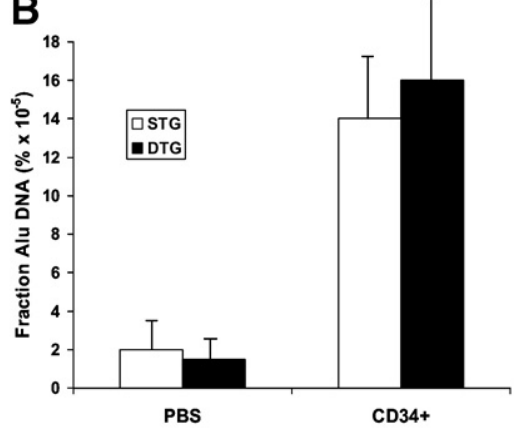

Figure 2. Real-time RT-PCR analysis of human Alu se quences in murine lung lysates at 8 weeks after inoculation. A: Alu-DNA index (amount of Alu-amplified DNA in CB$\mathrm{CD}_{3}{ }^{+}$recipient lungs relative to that detected in PBStreated nontransplanted lungs). B: Fraction of Alu DNA (percentage of human DNA relative to total lung DNA content). Values represent the mean \pm SD of at least three animals per group. STG indicates single transgenic; DTG, double transgenic.
Figure 5, A-C). In contrast, SP-C staining was easily detected in a significantly larger fraction of human-derived epithelial cells in the lungs of double-transgenic mice (Figure 4 and Figure 5, D-L). In both types of transgenic recipients, the intensity of SP-C immunoreactivity appeared lower in CB-derived surfactant-producing epithelial cells than in resident murine alveolar type II cells (Figure 5, A-L). Surfactant-positive granular material, consistent with surfactant-containing lamellar bodies, was often seen in close approximation to, or even protruding from, the cell membrane, likely representing morphological evidence of exocytosis (Figure 5, G-I).

An examination of the parenchyma surrounding large and ovoid or spherical CB-derived surfactant-containing type II-like cells revealed the frequent presence of more elongated cells containing small cytoplasmic aggregates of immunoreactive surfactant and human cytokeratin (Figure 5, D-I). These cells were highly suggestive of so-called transitional cells, which have phenotypical characteristics intermediate between type II cells (surfactant content) and type I cells (flat elongated shape). The apparent existence of CB-derived transitional cells suggests that human-derived alveolar type II-like cells may be capable of generating alveolar type I cells, analogous to the function of native alveolar type II cells. In support of the potential progenitor capacity of the CB-derived surfactant-containing epithelial cells, mitotic activity

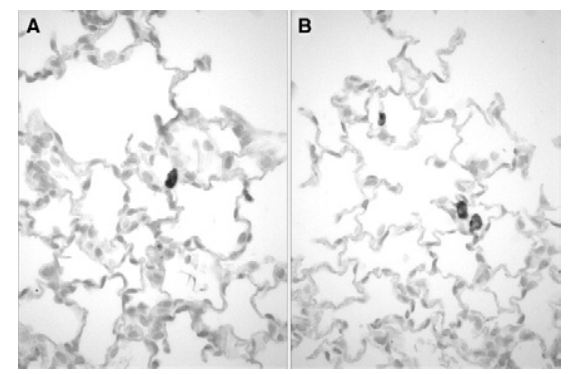

Figure 3. Analysis of epithelial differentiation of engrafted $\mathrm{CB}-\mathrm{CD} 34^{+}$cells by human cytokeratin immunohistochemistry at 8 weeks after inoculation. A: Single-transgenic recipient. Representative staining result showing a large, ovoid, CB-derived, cytokeratin-positive epithelial cell in the alveolar wall. B: Double-transgenic recipient. Several human-derived cytokeratin-positive epithelial cells are noted within the alveolar septa. Two large spherical cells with morphological appearance of alveolar type II cells are noted in close proximity to each other. Murine lung epithelial cells are not stained, confirming the species specificity of the anti-human cytokeratin antibody (avidin-biotin peroxidase, hematoxylin counterstain; original magnification, $\times 600)$. was occasionally detected in CB-derived type II-like cells (Figure $5, \mathrm{~J}-\mathrm{L}$ ).

To establish further the potential of human CB-derived type II-like cells to generate alveolar type I cells, we assessed the presence of human-derived type I cells in the proximity of human-derived type II-like cells. By using the same double-immunofluorescence approach, human cytokeratin labeling was combined with anti-T1 $\alpha$ (podoplanin) staining (as a marker of alveolar type I cells). ${ }^{62}$ Colocalization of immunoreactive human cytokeratin and T1 $\alpha$ could be seen in cells surrounding CB-derived type II-like epithelial cells (Figure 5, M-O), suggesting that at least some of the type I cells surrounding CB-derived type II-like cells are human derived as well.

Finally, we combined anti-human cytokeratin staining with anti-CCSP labeling to determine possible generation of bronchial epithelial cells from CB stem cells. Colocalization of human cytokeratin and CCSP was not observed (data not shown), suggesting that differentiation of human CB-CD34 ${ }^{+}$cells to bronchial epithelial CCSP cells was a rare event in this model, if it occurred at all.

\section{Analysis of Proliferation}

To explore further the possibility of clonal expansion of CB-derived respiratory epithelial cells, we studied whether CB-derived cells were undergoing proliferation. As shown in Figure 5, J-L, mitotic activity could be observed in CB-derived surfactant-producing type IIlike epithelial cells. Proliferation of engrafted CB-derived cells was formally assessed by combining human Alu-FISH analysis with anti-Ki-67 immunofluorescence staining. Colocalization of $\mathrm{Ki}-67$ and human Alu-FISH positivity to the same nuclei was readily observed in single- and double-transgenic recipients (Figure 6, A-F). Occasionally, clustering of Ki-67-positive CB-derived cells was suggestive of clonal proliferation (Figure 6, D-F). As shown in Figure 7, the proliferative activity of CB-derived cells was significantly higher in doubletransgenic animals compared with single-transgenic littermates, suggesting that proliferation of engrafted cells is promoted by lung injury. In both types of transgenic recipients, the proliferative activity was significantly higher in CB-derived cells than in native murine parenchymal cells (Figure 7).

To verify the proliferative potential of CB-derived epithelial cells, Ki-67 labeling was combined with human 


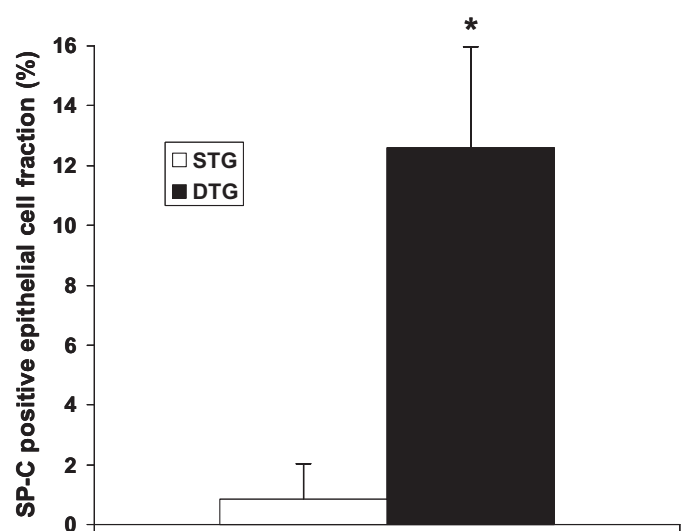

Figure 4. Fraction of SP-C-immunoreactive CB-derived epithelial cells at 8 weeks after inoculation. Values represent the mean \pm SD of at least three animals per group, expressed as a percentage. ${ }^{*} P<0.01$. STG indicates single transgenic; DTG, double transgenic.

cytokeratin staining. Proliferative activity was readily observed in CB-derived cytokeratin-immunoreactive type II cell-like cells in single- and double-transgenic animals (Figure 6, G-L). These results demonstrate that human CB-CD $34^{+}$cells or their progeny, including respiratory epithelial cells, have the capacity for proliferation up to 8 weeks after intranasal inoculation.

\section{Analysis of Cell Fusion}

To determine whether cellular fusion of human and murine cells may be implicated in the respiratory epithelial differentiation of $\mathrm{CB}-\mathrm{CD} 34^{+}$cells observed in our model, we combined FISH analysis using human Alu probes with $\mathrm{FISH}$ analysis using pancentromeric murine chromosome probes. Color-coded dual FISH analysis allowed unequivocal differentiation between human and murine nuclei: human CB-derived nuclei were identified by diffuse intense green staining, whereas murine nuclei displayed a dotlike red staining pattern, corresponding to centromeric hybridization (Figure 6, M-R). Double FISH analysis using species-specific probes failed to reveal the presence of murine genomic material in numerous (>200) human-derived nuclei examined, suggesting that fusion of human CB-CD34 ${ }^{+}$cells (or their progeny) with murine cells is not a dominant mechanism of generation of differentiated CB-derived cells in our model.

\section{Discussion}

In this study, we demonstrated that human umbilical CBderived $\mathrm{CD}_{3}{ }^{+}$cells, delivered to newborn mice with injured lungs via intranasal inoculation, have the capacity to generate alveolar epithelial cells in vivo. By using stateof-the-art confocal microscopy techniques to circumvent the pitfalls of overlay and other imaging artifacts, we demonstrated further that the human CB-derived alveolar epithelial cells have several critical phenotypic characteristics in common with resident alveolar epithelial types I and II cells. Some CB-derived epithelial cells were relatively large and cuboidal or spherical, contained surfactant,

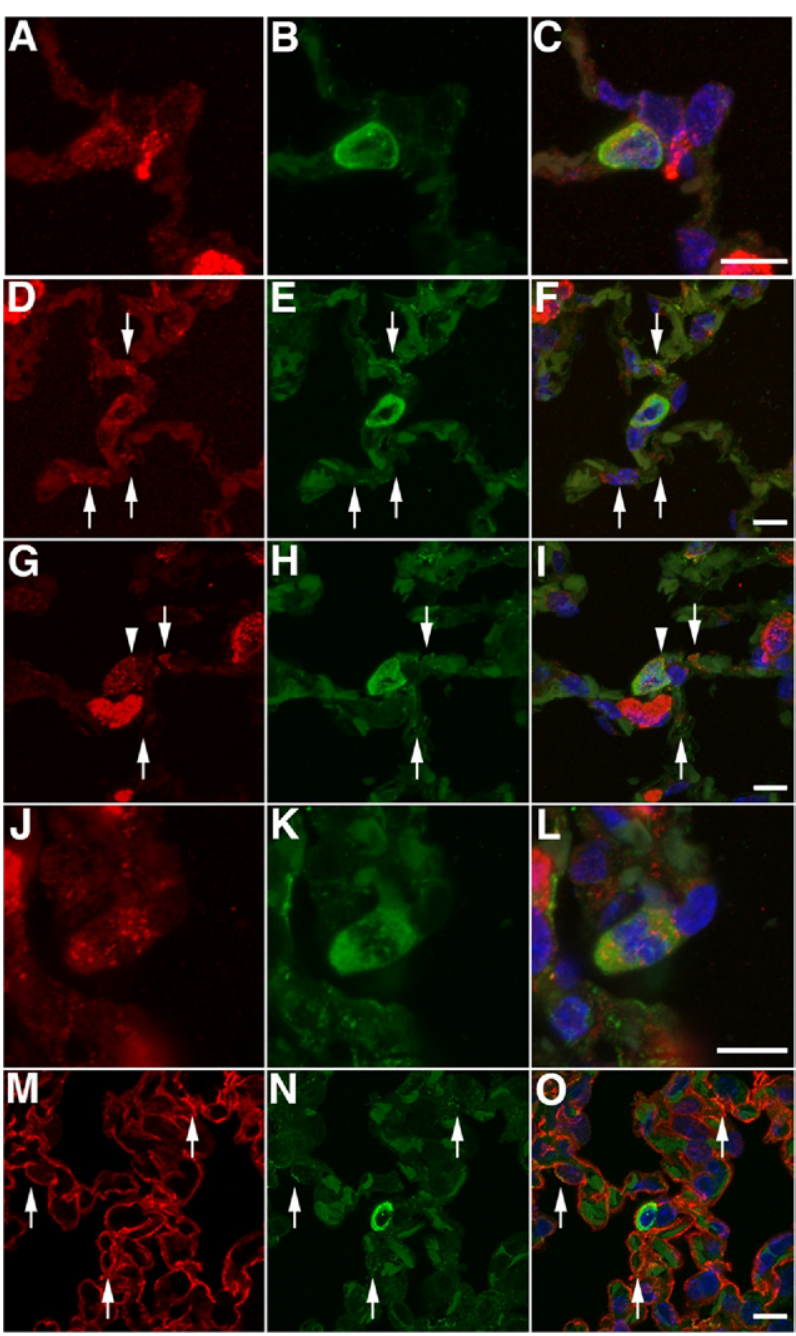

Figure 5. Analysis of respiratory epithelial differentiation of engrafted CB$\mathrm{CD} 4^{+}$cells at 8 weeks after inoculation. A-C: Single-transgenic recipient. Combined anti-human cytokeratin (green) and anti-mouse/human SP-C (red) immunofluorescence staining showing one of rare SP-C-positive humanderived epithelial cells detected in the lungs of single-transgenic animals [anti-human cytokeratin (green) staining combined with anti-SP-C staining (red), DAPI counterstain]. D-F: Double-transgenic recipient. Colocalization of immunoreactive human cytokeratin and SP-C in CB-derived type II-like epithelial cell within the alveolar wall. Arrows indicate the presence of surfactant and human cytokeratin-immunoreactive material in adjacent elongated cells, suggestive of intermediate cells generated during the transition from type II to type I cells. A resident murine type II cell is noted in the left upper corner [anti-human cytokeratin (green) staining combined with antiSP-C staining (red), DAPI counterstain]. G-I: Double-transgenic recipient. Another example of a human CB-derived type II-like cell, characterized by the large size, ovoid shape, and presence of abundant human cytokeratinand SP-C-immunoreactive material in the cytoplasm. Granular surfactant staining, consistent with lamellar bodies, is noted in a juxtamembranous location, suggestive of secretory activity (exocytosis) (arrowhead). Adjacent cells with an elongated cell shape contain surfactant-immunoreactive material and human cytokeratin, consistent with transitional type II-type I cells (arrows) [anti-human cytokeratin (green) staining combined with anti-SP-C staining (red), DAPI counterstain]. J-L: Double-transgenic recipient. Human CB-derived surfactant-producing type II-like epithelial cell undergoing mitosis [anti-human cytokeratin (green) staining combined with anti-SP-C staining (red), DAPI counterstain]. M-O: Double-transgenic recipient. Cellular colocalization of T1 $\alpha$ (red) and human cytokeratin (green) is noted in attenuated cells adjacent to human CB-derived type II-like cells (arrows), suggestive of CB-derived type I cells. The CB-derived type II-like cell is incorporated deeply within the alveolar wall and partially covered by type I cell extensions [anti-human cytokeratin (green) staining combined with anti-T1 $\alpha$ staining (red), DAPI counterstain]. Scale bar $=10 \mu \mathrm{m}$. 

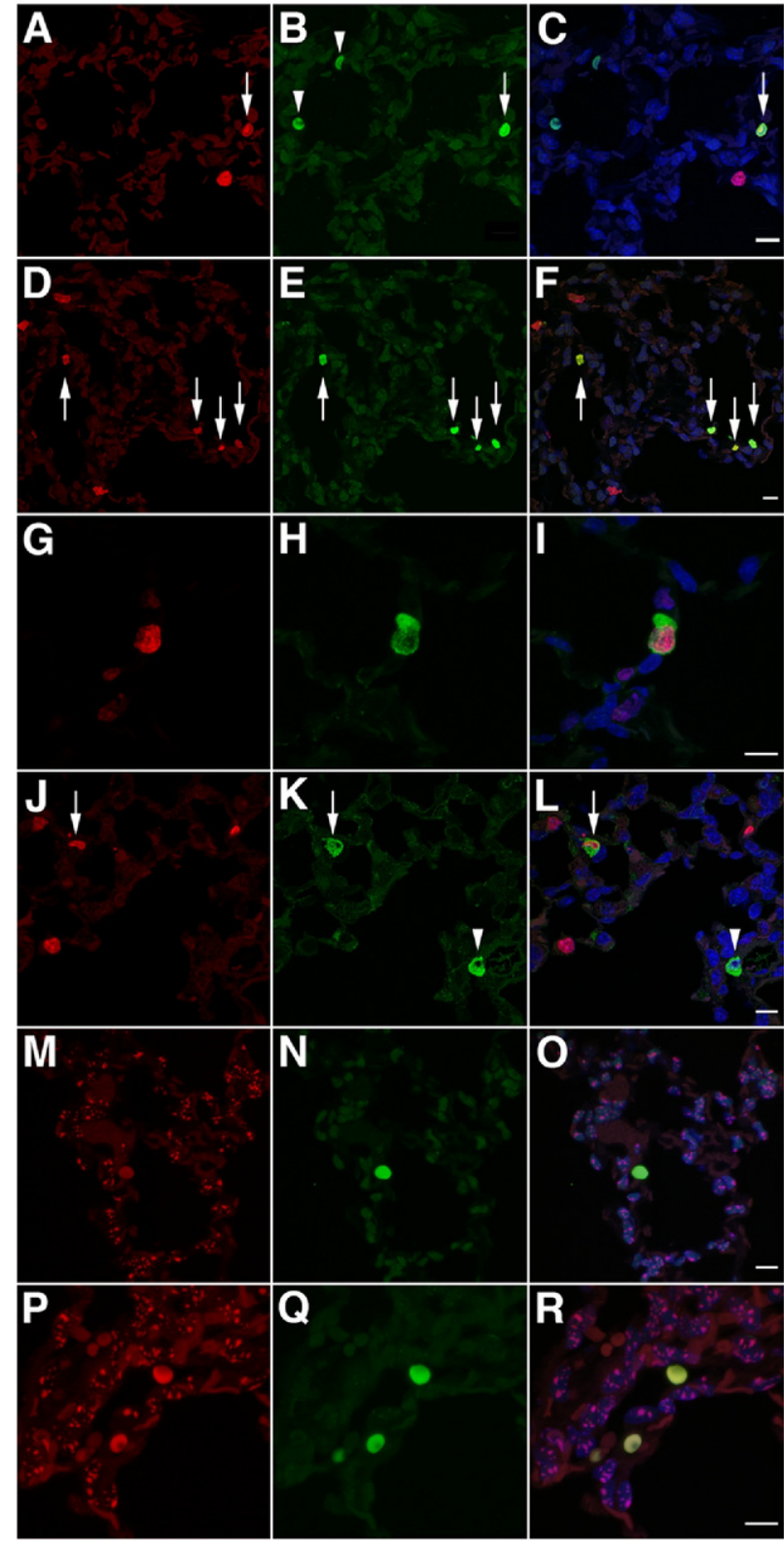

Figure 6. Analysis of proliferation and cell fusion of engrafted $\mathrm{CB}-\mathrm{CD} 34^{+}$cells a 8 weeks after inoculation. A-C: Single-transgenic recipient. Combined anti-Ki-67 immunofluorescence (red) and Alu FISH analysis (green). Shown are two nonproliferating CB-derived cells (arrowheads), a proliferating CB-derived cell (arrow) and a proliferating murine cell (red) [FISH analysis using human Alu-specific probes (green) combined with anti-Ki-67 immunofluorescence (red), DAPI counterstain] D-F: Double-transgenic recipient. Combined anti-Ki- 67 immunofluorescence (red) and Alu FISH analysis (green). Shown are four Ki-67-positive proliferating CBderived cells (arrows), three of which are in contiguity, suggestive of clonal expansion. Several proliferating murine nuclei (red) are noted [FISH analysis using human Alu-specific probes (green) combined with anti-Ki-67 immunofluorescence (red) DAPI counterstain]. G-I: Single-transgenic recipient. Combined anti-Ki-67 (red) and anti-human cytokeratin (green) immunofluorescence showing a Ki-67-positive proliferating human-derived epithelial cell [anti-human cytokeratin (green) and antiKi-67 (red) immunofluorescence, DAPI counterstain]. J-L: Double-transgenic recipient. Combined anti-Ki-67 (red) and anti-human cytokeratin (green) immunofluorescence. Representative micrograph showing a nonproliferating CB-derived epithelial cell (arrowhead), a proliferating CB-derived epithelial cell (arrow), and proliferating murine cells (red) [anti-human cytokeratin (green) and anti-Ki-67 (red) immunofluorescence, DAPI counterstain]. M-O: Single-transgenic recipient. P-R Double-transgenic recipient. Double FISH analysis using human Alu-specific probes (green) combined with mouse-specific pancentromeric probes (red). The murine FISH signal is absent in nuclei of human CB-derived cells [FISH analysis using human Alu-specific probes (green) combined with FISH analysis using mouse-specific pancentromeric probes (red), DAPI counterstain]. Scale bar $=10 \mu \mathrm{m}$.

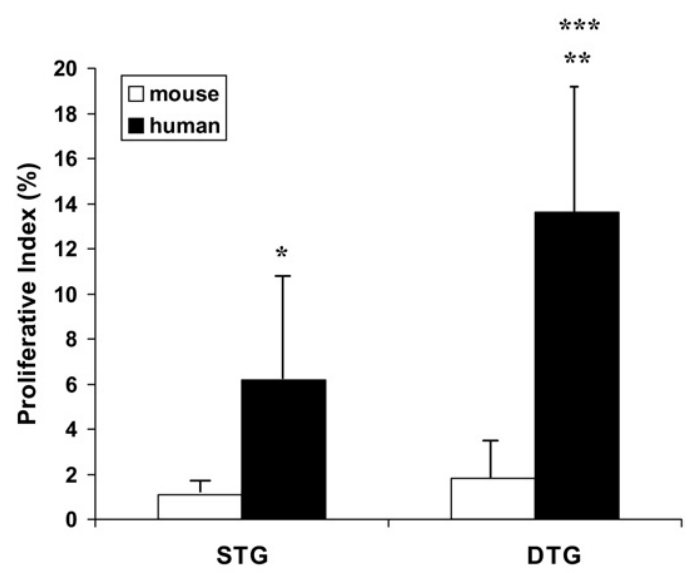

Figure 7. Proliferative activity of engrafted CB-derived cells at 8 weeks after inoculation. Fraction of Ki-67-positive murine nuclei ("mouse") and Alu FISH-positive CB-derived nuclei ("human"), expressed as a percentage. Values represent the mean \pm SD of at least three animals per group. ${ }^{*} P<0.05$ and ${ }^{* *} P<0.01$ versus murine cells; and ${ }^{* * * *} P<0.05$ versus single-transgenic animals. STG indicates single transgenic; DTG, double transgenic

and were capable of replication, similar to native alveolar type II cells. Other CB-derived epithelial cells had an elongated shape and ovoid nuclei and contained membraneassociated immunoreactive podoplanin $(T 1 \alpha)$, which is a marker of alveolar type I cells. ${ }^{62}$

Based on the seminal work by Evans et $\mathrm{al}^{63}$ and Adamson and Bowden ${ }^{64}$ more than three decades ago, the accepted paradigm of alveolar epithelial cell lineage and differentiation is that type II cells act as progenitor cells of the alveolar epithelium of the distal respiratory unit. ${ }^{65}$ Alveolar type II cells have the capacity to replicate and, by symmetric or asymmetric division, generate type II cells and/or type I cells. Type I cells, in contrast, are generally believed to be terminally differentiated and do not have the capacity to proliferate.

The coexistence of both types II and I cell-like CBderived epithelial cells, often in proximity to each other, suggests that the CB-derived type II-like cells may be capable of assuming the function of progenitor of the terminal respiratory unit, analogous to the role of resident alveolar epithelial type II cells. The potential generation of type I cells from replicating CB-derived type II cells was supported by the abundant proliferative activity of CB-derived type II cell-like epithelial cells and the identification of CB-derived hybrid cells with a phenotype intermediate between type II and type I cells adjacent to CB-derived type II cell-like epithelial cells. Such transitional cells with characteristics of both type I and type II cells were first described at the ultrastructural level, ${ }^{63,66,67}$ where the existence of cells with the flattened shape of type I cells, combined with the irregular nucleus, microvilli, and residual lamellar bodies of type II cells, was interpreted as evidence of the progenitor role of type II cells. ${ }^{64}$

Although surfactant immunoreactivity is routinely accepted as a marker of alveolar type II cells, the phenotypic characteristics of CB-derived surfactant-producing epithelial cells need to be investigated further before these cells can be considered as transdifferentiated, ma- 
ture, alveolar type II cells. For instance, the functional characteristics of surfactant synthesis and secretion by the CB-derived surfactant-producing epithelial cells need to be compared with those of native human alveolar type II cells. Although exocytosis and, therefore, the secretory machinery appeared to be functional in CB-derived cells in the present study, their cytoplasmic surfactant content seemed to be lower than that of adjacent murine type II cells.

Engrafted cells were readily detected in single- and double-transgenic recipient animals. These results corroborate previous observations ${ }^{24}$ with bone marrowtreated hyperoxic newborn mice and suggest that the inherently high cell turnover of newborn lungs may be sufficient to facilitate stem cell engraftment, as opposed to adult lungs in which cell injury appears to be a prerequisite for effective stem cell engraftment. The recovery rates of CB-derived cells at 8 weeks after inoculation were similar in single- and double-transgenic animals. However, the proliferative activity of CB-derived cells at this point was significantly higher in double-transgenic animals. To reconcile these findings, we speculate that the initial engraftment efficiency may have been lower in double-transgenic FasL-overexpressing animals. Although initially detrimental, the injury milieu may have promoted subsequent "catch-up" proliferation in surviving engrafted cells, allowing them to reach numbers equivalent to those of noninjured single-transgenic animals by postinoculation week 8 .

The incidence of CB-derived surfactant-positive epithelial cells was significantly higher in double-transgenic animals than in single-transgenic littermates, suggesting that lung injury promoted phenotypic conversion of CBderived $\mathrm{CD} 34^{+}$cells to alveolar epithelial cells. The exact mechanisms underlying injury-associated induction of proliferation and respiratory epithelial differentiation of $\mathrm{CD}_{4}{ }^{+}$progenitor cells remain to be determined.

We also investigated the mechanisms underlying the generation of alveolar epithelial cells from human CBderived $\mathrm{CD} 34^{+}$cells. Two major mechanisms may account for the contribution of hematopoietic (bone marrow-derived or other) stem cells to adult tissue regeneration. One mechanism assumes a change in gene expression in response to the tissue microenvironment, a process referred to as transdifferentiation. ${ }^{68-71}$ According to the second proposed mechanism, changes in gene expression occur through fusion of hematopoietic stem cells with preexisting mature cells. ${ }^{59,60,72}$ The fusion of hematopoietic cells and tissue-specific host cells is a mechanism of generation of "transdifferentiated" cells from bone marrow in the liver, brain, and heart. ${ }^{59-61,72-74}$

Cell fusion in most systems is characterized by the coexistence of donor and recipient genomic material in the same nucleus. ${ }^{59-61}$ Our xenogeneic model allowed assessment of possible cell fusion by double FISH analysis using species-specific probes. Double FISH studies failed to reveal the presence of murine genomic material in human-derived nuclei, suggesting that the generation of human CB-derived epithelial cells may be mediated exclusively or predominantly through fusion-independent mechanisms. Our experimental technique does not allow detection of other forms of fusion, such as lateral transfer between cells of microvesicles containing mRNA and proteins. ${ }^{75}$

To our knowledge, this is the first study to demonstrate that human $\mathrm{CB}$-derived $\mathrm{CD} 34^{+}$cells are capable of reconstituting injured alveolar epithelium. This occurs by stable and long-term engraftment, functional differentiation, replication, and clonogenic expansion. Although these results have promising translational potential for the use of autologous or heterologous CB-derived CD34 ${ }^{+}$ cells in a wide range of pulmonary diseases, characterized by injured, deficient, or defective respiratory epithelium, several important issues remain to be addressed.

First, the subpopulation of $\mathrm{CD} 34^{+}$cells most prone to undergo engraftment and secondary transdifferentiation to alveolar epithelial cells needs to be dissected from the heterogeneous $\mathrm{CD}_{3} 4^{+}$cell population. Second, techniques need to be developed to increase the initial graft size, focusing on the most relevant $\mathrm{CD} 34^{+}$cell subtype. Approaches to increase the $\mathrm{CD} 34^{+}$cell number may include ex vivo expansion (preferably in culture conditions favoring subsequent engraftment and alveolar epithelial transdifferentiation) and/or combinations of multiple donor placentas. Third, the engraftment and transdifferentiation potential of preterm, rather than term, $\mathrm{CD}_{4}{ }^{+}$cells needs to be established. Finally, and most critically, the long-term outcome and safety of the CBderived chimeric alveolar epithelial cells need to be studied before clinical use of $\mathrm{CB}$-derived $\mathrm{CD} 34^{+}$stem cell transplantation in the vulnerable newborn population may be contemplated.

Some limitations of this study are acknowledged. Because this study was mainly designed to establish the proof of concept that $\mathrm{CB}$-derived $\mathrm{CD} 34^{+}$cells have the potential to generate alveolar epithelial cells, we did not formally assess the effects of the engrafted cells on alveolar remodeling. Encouraged by the demonstrated transdifferentiation potential of $\mathrm{CB}-\mathrm{CD} 34^{+}$cells, new studies using larger graft sizes are in progress to determine the potential effects of $\mathrm{CB}-\mathrm{CD} 34^{+}$cells on lung growth kinetics and alveolarization. Second, we did not study the fate of engrafted CB-derived cells that did not undergo epithelial differentiation. We speculate that some cells may have persisted as undifferentiated primitive cells in the hematopoietic lineage, whereas other cells may have differentiated to various nonepithelial cell types (including mesenchymal cells).

The observations made in this study offer the first solid evidence that CB-derived hematopoietic stem cells, delivered intratracheally, may be capable of reconstituting injured alveolar epithelium. The demonstrated in vivo capacity of CB-derived hematopoietic progenitor cells to transdifferentiate into alveolar epithelial cells that display the surfactant production, replicative potential, and apparent progenitor function characteristic of endogenous alveolar epithelial type II cells encourages the future use of $\mathrm{CB}$-derived cells in regenerative pulmonary medicine. Knowledge acquired from studies in the developing lung may also be relevant for adult diseases characterized by alveolar injury, including acute respiratory distress syndrome and emphysema. 


\section{Acknowledgments}

We thank Ms. Terese Pasquariello for assistance with immunohistochemical analyses; Drs. Debra EricksonOwens and Judith Mercer for technical assistance with CB harvesting; Francois I. Luks, M.D., Ph.D., for helpful comments and critical review of the manuscript; Umadevi Tantravahi, Ph.D., for performing and interpreting the FISH analyses with human centromeric probes; and an anonymous donor for providing support for stem cell research at Women and Infants Hospital. The 8.1.1 antibody developed by Andrew G. Farr, Ph.D., was obtained from the Developmental Studies Hybridoma Bank, under the auspices of the National Institute of Child Health and Human Development, and maintained by the Department of Biological Sciences, University of lowa, lowa City.

\section{References}

1. Jobe AH, Bancalari E: Bronchopulmonary dysplasia. Am J Respir Crit Care Med 2001, 163:1723-1729

2. Husain AN, Siddiqui NH, Stocker JT: Pathology of arrested acinar development in postsurfactant bronchopulmonary dysplasia. Hum Pathol 1998, 29:710-717

3. Jobe AJ: The new BPD: an arrest of lung development. Pediatr Res 1999, 46:641-643

4. De Paepe ME, Mao Q, Powell J, Rubin SE, DeKoninck P, Appel N, Dixon M, Gundogan F: Growth of pulmonary microvasculature in ventilated preterm infants. Am J Respir Crit Care Med 2006, 173:204211

5. Hargitai B, Szabo V, Hajdu J, Harmath A, Pataki M, Farid P, Papp Z, Szende B: Apoptosis in various organs of preterm infants: histopathologic study of lung, kidney, liver, and brain of ventilated infants. Pediatr Res 2001, 50:110-114

6. Lukkarinen HP, Laine J, Kaapa PO: Lung epithelial cells undergo apoptosis in neonatal respiratory distress syndrome. Pediatr Res 2003, 53:254-259

7. May M, Strobel P, Preisshofen T, Seidenspinner S, Marx A, Speer CP. Apoptosis and proliferation in lungs of ventilated and oxygen-treated preterm infants. Eur Respir J 2004, 23:113-121

8. De Paepe ME, Gundavarapu S, Tantravahi U, Pepperell JR, Haley SA, Luks FI, Mao Q: Fas-ligand-induced apoptosis of respiratory epithelial cells causes disruption of postcanalicular alveolar development. Am J Pathol 2008, 173:42-56

9. Sueblinvong V, Loi R, Eisenhauer PL, Bernstein IM, Suratt BT, Spees $\mathrm{JL}$, Weiss DJ: Derivation of lung epithelium from human cord bloodderived mesenchymal stem cells. Am J Respir Crit Care Med 2008, 177:701-711

10. Macpherson H, Keir P, Webb S, Samuel K, Boyle S, Bickmore W, Forrester L, Dorin J: Bone marrow-derived SP cells can contribute to the respiratory tract of mice in vivo. J Cell Sci 2005, 118:2441-2450

11. MacPherson H, Keir PA, Edwards CJ, Webb S, Dorin JR: Following damage, the majority of bone marrow-derived airway cells express an epithelial marker. Respir Res 2006, 7:145

12. Loi R, Beckett T, Goncz KK, Suratt BT, Weiss DJ: Limited restoration of cystic fibrosis lung epithelium in vivo with adult bone marrowderived cells. Am J Respir Crit Care Med 2006, 173:171-179

13. Yan C, Lian X, Dai Y, Wang X, Qu P, White A, Qin Y, Du H: Gene delivery by the hSP-B promoter to lung alveolar type II epithelial cells in LAL-knockout mice through bone marrow mesenchymal stem cells. Gene Ther 2007, 14:1461-1470

14. Serikov VB, Popov B, Mikhailov VM, Gupta N, Matthay MA: Evidence of temporary airway epithelial repopulation and rare clonal formation by BM-derived cells following naphthalene injury in mice. Anat Rec (Hoboken) 2007, 290:1033-1045

15. Wong AP, Dutly AE, Sacher A, Lee H, Hwang DM, Liu M, Keshavjee S, Hu J, Waddell TK: Targeted cell replacement with bone marrow cells for airway epithelial regeneration. Am J Physiol Lung Cell Mol Physiol 2007, 293:L740-L752
16. Bruscia EM, Price JE, Cheng EC, Weiner S, Caputo C, Ferreira EC, Egan ME, Krause DS: Assessment of cystic fibrosis transmembrane conductance regulator (CFTR) activity in CFTR-null mice after bone marrow transplantation. Proc Natl Acad Sci U S A 2006, 103:29652970

17. Bruscia EM, Ziegler EC, Price JE, Weiner S, Egan ME, Krause DS: Engraftment of donor-derived epithelial cells in multiple organs following bone marrow transplantation into newborn mice. Stem Cells 2006, 24:2299-2308

18. Spees JL, Pociask DA, Sullivan DE, Whitney MJ, Lasky JA, Prockop DJ, Brody AR: Engraftment of bone marrow progenitor cells in a rat model of asbestos-induced pulmonary fibrosis. Am J Respir Crit Care Med 2007, 176:385-394

19. Raoul W, Wagner-Ballon O, Saber G, Hulin A, Marcos E, Giraudier S, Vainchenker W, Adnot S, Eddahibi S, Maitre B: Effects of bone marrow-derived cells on monocrotaline- and hypoxia-induced pulmonary hypertension in mice. Respir Res 2007, 8:8

20. Weiss DJ, Kolls JK, Ortiz LA, Panoskaltsis-Mortari A, Prockop DJ: Stem cells and cell therapies in lung biology and lung diseases. Proc Am Thorac Soc 2008, 5:637-667

21. Kotton DN, Fabian AJ, Mulligan RC: Failure of bone marrow to reconstitute lung epithelium. Am J Respir Cell Mol Biol 2005, 33:328-334

22. Wagers AJ, Sherwood RI, Christensen JL, Weissman IL: Little evidence for developmental plasticity of adult hematopoietic stem cells. Science 2002, 297:2256-2259

23. Chang JC, Summer R, Sun X, Fitzsimmons K, Fine A: Evidence that bone marrow cells do not contribute to the alveolar epithelium. Am J Respir Cell Mol Biol 2005, 33:335-342

24. Fritzell JA Jr, Mao Q, Gundavarapu S, Pasquariello T, Aliotta JM, Ayala A, Padbury JF, De Paepe ME: Fate and effects of adult bone marrow cells in lungs of normoxic and hyperoxic newborn mice. Am J Respir Cell Mol Biol 2009, 40:575-587

25. Rojas M, Xu J, Woods CR, Mora AL, Spears W, Roman J, Brigham KL: Bone marrow-derived mesenchymal stem cells in repair of the injured lung. Am J Respir Cell Mol Biol 2005, 33:145-152

26. Spees JL, Whitney MJ, Sullivan DE, Lasky JA, Laboy M, Ylostalo J, Prockop DJ: Bone marrow progenitor cells contribute to repair and remodeling of the lung and heart in a rat model of progressive pulmonary hypertension. FASEB J 2008, 22:1226-1236

27. Aliotta JM, Keaney P, Passero M, Dooner MS, Pimentel J, Greer D, Demers D, Foster B, Peterson A, Dooner G, Theise ND, Abedi M, Colvin GA, Quesenberry PJ: Bone marrow production of lung cells: the impact of G-CSF, cardiotoxin, graded doses of irradiation, and subpopulation phenotype. Exp Hematol 2006, 34:230-241

28. Nakahata T, Ogawa M: Hemopoietic colony-forming cells in umbilical cord blood with extensive capability to generate mono- and multipotential hemopoietic progenitors. J Clin Invest 1982, 70:1324-1328

29. Broxmeyer HE, Douglas GW, Hangoc G, Cooper S, Bard J, English D, Arny M, Thomas L, Boyse EA: Human umbilical cord blood as a potential source of transplantable hematopoietic stem/progenitor cells. Proc Natl Acad Sci U S A 1989, 86:3828-3832

30. Erices $\mathrm{A}$, Conget $\mathrm{P}$, Minguell $\mathrm{JJ}$ : Mesenchymal progenitor cells in human umbilical cord blood. Br J Haematol 2000, 109:235-242

31. Berger MJ, Adams SD, Tigges BM, Sprague SL, Wang XJ, Collins DP, McKenna DH: Differentiation of umbilical cord blood-derived multilineage progenitor cells into respiratory epithelial cells. Cytotherapy 2006, 8:480-487

32. Kim JW, Kim SY, Park SY, Kim YM, Kim JM, Lee MH, Ryu HM: Mesenchymal progenitor cells in the human umbilical cord. Ann Hematol 2004, 83:733-738

33. Goldberg JL, Laughlin MJ, Pompili VJ: Umbilical cord blood stem cells: implications for cardiovascular regenerative medicine. J Mol Cell Cardiol 2007, 42:912-920

34. van de Ven C, Collins D, Bradley MB, Morris E, Cairo MS: The potential of umbilical cord blood multipotent stem cells for nonhematopoietic tissue and cell regeneration. Exp Hematol 2007, 35:17531765

35. Garbuzova-Davis S, Willing AE, Zigova T, Saporta S, Justen EB, Lane JC, Hudson JE, Chen N, Davis CD, Sanberg PR: Intravenous administration of human umbilical cord blood cells in a mouse model of amyotrophic lateral sclerosis: distribution, migration, and differentiation. J Hematother Stem Cell Res 2003, 12:255-270 
36. Dai Y, Li J, Dai G, Mu H, Wu Q, Hu K, Cao Q: Skin epithelial cells in mice from umbilical cord blood mesenchymal stem cells. Burns 2007 , 33:418-428

37. Harris DT, Badowski M, Ahmad N, Gaballa MA: The potential of cord blood stem cells for use in regenerative medicine. Expert Opin Biol Ther 2007, 7:1311-1322

38. Almeida-Porada G, Porada CD, Chamberlain J, Torabi A, Zanjani ED: Formation of human hepatocytes by human hematopoietic stem cells in sheep. Blood 2004, 104:2582-2590

39. Hirata Y, Sata M, Motomura N, Takanashi M, Suematsu Y, Ono M, Takamoto S: Human umbilical cord blood cells improve cardiac function after myocardial infarction. Biochem Biophys Res Commun 2005 327:609-614

40. Sharma AD, Cantz T, Richter R, Eckert K, Henschler R, Wilkens L, Jochheim-Richter A, Arseniev L, Ott M: Human cord blood stem cells generate human cytokeratin 18-negative hepatocyte-like cells in injured mouse liver. Am J Pathol 2005, 167:555-564

41. Wang TT, Tio M, Lee W, Beerheide W, Udolph G: Neural differentiation of mesenchymal-like stem cells from cord blood is mediated by PKA. Biochem Biophys Res Commun 2007, 357:1021-1027

42. Di Campli C, Piscaglia AC, Rutella S, Bonanno G, Vecchio FM, Zocco MA, Monego G, Michetti F, Mancuso S, Pola P, Leone G, Gasbarrini G. Gasbarrini A: Improvement of mortality rate and decrease in histologic hepatic injury after human cord blood stem cell infusion in a murine model of hepatotoxicity. Transplant Proc 2005, 37:27072710

43. Ishikawa F, Yasukawa M, Yoshida S, Nakamura K, Nagatoshi Y Kanemaru T, Shimoda K, Shimoda S, Miyamoto T, Okamura J, Shultz LD, Harada M: Human cord blood- and bone marrow-derived CD34+ cells regenerate gastrointestinal epithelial cells. FASEB J 2004, 18: 1958-1960

44. Yoshida S, Ishikawa F, Kawano N, Shimoda K, Nagafuchi S, Shimoda S, Yasukawa M, Kanemaru T, Ishibashi H, Shultz LD, Harada M: Human cord blood-derived cells generate insulin-producing cells in vivo. Stem Cells 2005, 23:1409-1416

45. Chang YS, Oh W, Choi SJ, Sung DK, Kim SY, Choi EY, Kang S, Jin HJ, Yang YS, Park WS: Human umbilical cord blood-derived mesenchymal stem cells attenuate hyperoxia-induced lung injury in neonatal rats. Cell Transplant 2009, 18:869-886

46. Moodley Y, Atienza D, Manuelpillai U, Samuel CS, Tchongue J, llancheran S, Boyd R, Trounson A: Human umbilical cord mesenchymal stem cells reduce fibrosis of bleomycin-induced lung injury. Am J Pathol 2009, 175:303-313

47. Brody AR, Salazar KD, Lankford SM: Mesenchymal stem cells modulate lung injury. Proc Am Thorac Soc 2010, 7:130-133

48. Tolar J, Nauta AJ, Osborn MJ, Panoskaltsis Mortari A, McElmurry RT, Bell S, Xia L, Zhou N, Riddle M, Schroeder TM, Westendorf JJ, Mclvor RS, Hogendoorn PC, Szuhai K, Oseth L, Hirsch B, Yant SR, Kay MA, Peister A, Prockop DJ, Fibbe WE, Blazar BR: Sarcoma derived from cultured mesenchymal stem cells. Stem Cells 2007, 25:371-379

49. Wang Y, Huso DL, Harrington J, Kellner J, Jeong DK, Turney J, McNiece IK: Outgrowth of a transformed cell population derived from normal human BM mesenchymal stem cell culture. Cytotherapy 2005 , 7:509-519

50. Aguilar S, Nye E, Chan J, Loebinger M, Spencer-Dene B, Fisk N Stamp G, Bonnet D, Janes SM: Murine but not human mesenchymal stem cells generate osteosarcoma-like lesions in the lung. Stem Cells 2007, 25:1586-1594

51. De Paepe ME, Haley SA, Lacourse Z, Mao Q: Effects of Fas-ligand overexpression on alveolar type $\|$ cell growth kinetics in perinatal murine lungs. Pediatr Res 2010, 68:57-62

52. Lee RJ, Fang Q, Davol PA, Gu Y, Sievers RE, Grabert RC, Gall JM, Tsang E, Yee MS, Fok H, Huang NF, Padbury JF, Larrick JW, Lum LG: Antibody targeting of stem cells to infarcted myocardium. Stem Cells 2007, 25:712-717

53. Zhao TC, Tseng A, Yano N, Tseng Y, Davol PA, Lee RJ, Lum LG, Padbury JF: Targeting human CD34+ hematopoietic stem cells with anti-CD45 x anti-myosin light-chain bispecific antibody preserves cardiac function in myocardial infarction. J Appl Physiol 2008, 104: 1793-1800

54. Tichelaar JW, Lu W, Whitsett JA: Conditional expression of fibroblast growth factor-7 in the developing and mature lung. J Biol Chem 2000 , 275:11858-11864
55. McBride C, Gaupp D, Phinney DG: Quantifying levels of transplanted murine and human mesenchymal stem cells in vivo by real-time PCR. Cytotherapy 2003, 5:7-18

56. Schormann W, Hammersen FJ, Brulport M, Hermes M, Bauer A, Rudolph C, Schug M, Lehmann T, Nussler A, Ungefroren $H$, Hutchinson J, Fandrich F, Petersen J, Wursthorn K, Burda MR, Brustle O, Krishnamurthi K, von Mach M, Hengstler JG: Tracking of human cells in mice. Histochem Cell Biol 2008, 130:329-338

57. Farr AG, Berry ML, Kim A, Nelson AJ, Welch MP, Aruffo A: Characterization and cloning of a novel glycoprotein expressed by stromal cells in T-dependent areas of peripheral lymphoid tissues. J Exp Med 1992, 176:1477-1482

58. Kotton DN, Ma BY, Cardoso WV, Sanderson EA, Summer RS, Williams MC, Fine A: Bone marrow-derived cells as progenitors of lung alveolar epithelium. Development 2001, 128:5181-5188

59. Terada N, Hamazaki T, Oka M, Hoki M, Mastalerz DM, Nakano Y, Meyer EM, Morel L, Petersen BE, Scott EW: Bone marrow cells adopt the phenotype of other cells by spontaneous cell fusion. Nature 2002 , 416:542-545

60. Vassilopoulos G, Wang PR, Russell DW: Transplanted bone marrow regenerates liver by cell fusion. Nature 2003, 422:901-904

61. Alvarez-Dolado M, Pardal R, Garcia-Verdugo JM, Fike JR, Lee HO, Pfeffer K, Lois C, Morrison SJ, Alvarez-Buylla A: Fusion of bonemarrow-derived cells with Purkinje neurons, cardiomyocytes and hepatocytes. Nature 2003, 425:968-973

62. Barth K, Blasche R, Kasper M: T1alpha/podoplanin shows raft-associated distribution in mouse lung alveolar epithelial E10 cells. Cell Physiol Biochem 2010, 25:103-112

63. Evans MJ, Cabral LJ, Stephens RJ, Freeman G: Transformation of alveolar type 2 cells to type 1 cells following exposure to $\mathrm{NO}_{2}$. Exp Mol Pathol 1975, 22:142-150

64. Adamson IY, Bowden DH: The type 2 cell as progenitor of alveolar epithelial regeneration: a cytodynamic study in mice after exposure to oxygen. Lab Invest 1974, 30:35-42

65. Dobbs LG, Johnson MD, Vanderbilt J, Allen L, Gonzalez R: The great big alveolar TI cell: evolving concepts and paradigms. Cell Physiol Biochem 2010, 25:55-62

66. Faulkner CS 2nd, Esterly JR: Ultrastructural changes in the alveolar epithelium in response to Freund's adjuvant. Am J Pathol 1971, 64:559-566

67. Evans MJ, Cabral LC, Stephens RJ, Freeman G: Acute kinetic response and renewal of the alveolar epithelium following injury by nitrogen dioxide. Chest 1974, 65(suppl):62S-65S

68. LaBarge MA, Blau HM: Biological progression from adult bone marrow to mononucleate muscle stem cell to multinucleate muscle fiber in response to injury. Cell 2002, 111:589-601

69. Lagasse E, Connors H, Al-Dhalimy M, Reitsma M, Dohse M, Osborne L, Wang X, Finegold M, Weissman IL, Grompe M: Purified hematopoietic stem cells can differentiate into hepatocytes in vivo. Nat Med 2000, 6:1229-1234

70. Krause DS, Theise ND, Collector MI, Henegariu O, Hwang S, Gardner R, Neutzel S, Sharkis SJ: Multi-organ, multi-lineage engraftment by a single bone marrow-derived stem cell. Cell 2001, 105:369-377

71. Mezey E, Chandross KJ, Harta G, Maki RA, McKercher SR: Turning blood into brain: cells bearing neuronal antigens generated in vivo from bone marrow. Science 2000, 290:1779-1782

72. Wang $X$, Willenbring $\mathrm{H}$, Akkari $\mathrm{Y}$, Torimaru $\mathrm{Y}$, Foster $\mathrm{M}, \mathrm{Al}$-Dhalimy $\mathrm{M}$, Lagasse E, Finegold M, Olson S, Grompe M: Cell fusion is the principal source of bone-marrow-derived hepatocytes. Nature 2003 422:897-901

73. Weimann JM, Johansson CB, Trejo A, Blau HM: Stable reprogrammed heterokaryons form spontaneously in Purkinje neurons after bone marrow transplant. Nat Cell Biol 2003, 5:959-966

74. Ying QL, Nichols J, Evans EP, Smith AG: Changing potency by spontaneous fusion. Nature 2002, 416:545-548

75. Aliotta JM, Sanchez-Guijo FM, Dooner GJ, Johnson KW, Dooner MS, Greer KA, Greer D, Pimentel J, Kolankiewicz LM, Puente N, Faradyan S, Ferland P, Bearer EL, Passero MA, Adedi M, Colvin GA, Quesenberry $\mathrm{PJ}$ : Alteration of marrow cell gene expression, protein production, and engraftment into lung by lung-derived microvesicles: a novel mechanism for phenotype modulation. Stem Cells 2007, 25:2245-2256 